\title{
VÝVOJ PROCESU ZÍSKÁVÁNÍ PRACOVNÍKŮ V PODNICÍCH
}

\section{Petra Bauerová}

\section{Klíčová slova:}

personální práce, způsoby výběru pracovníků, pracovní místo

\section{Key words:}

personnel work, methods of staff recruitment, work position

\begin{abstract}
Abstrakt
Významnou oblastí, která prošla poměrně zásadním vývojem na trhu práce, je metodika získávání a výběru pracovníků. Výběr vhodných pracovníků má strategický význam pro dlouhodobou úspěšnost a konkurenceschopnost organizace. Článek se v první části zabývá teoretickými východisky získávání a výběru pracovníků. Těžištěm práce je zpracovaný výzkum v oblasti získávání pracovníků a analýza změn, které se v této oblasti realizovaly.
\end{abstract}

\begin{abstract}
The methodology of the staff recruitment is an important area which has passed through the major development in the labour market. The selection of suitable workers has its strategic importance for the long term success and competitiveness of the organization. In the first part the article deals with the theoretical base of the staff recruitment. The research work is focused on the research in the area of the staff recruitment and the analysis of changes which were implemented in this field.
\end{abstract}

\section{Úvod}

V posledních letech zažívá trh práce zásadní změny. Významnou oblastí, která prošla zajímavým vývojem, je oblast získávání a výběru pracovníků. Výběr vhodných pracovníků představuje $\mathrm{v}$ dnešní době klíčovou až strategickou fázi pro dlouhodobou úspěšnost a konkurenceschopnost organizace. Pokud má být samotný výběr efektivní, je nutné, aby organizace použila adekvátní metody výběru, které plně korespondují s cílem daného výběru. Cílem samotného výběru nejvhodnějších pracovníků je v globále identifikovat a vybrat mezi uchazeči o práci ty, kteří nejenže budou vyhovovat požadavkům pracovního místa, podmínkám organizace, ale také budou schopni se stát platnými členy pracovního týmu. Cílem tohoto článku je poskytnout analýzu procesu získávání a výběru pracovníků a poukázat na změny tohoto procesu $\mathrm{v}$ čase.

\section{Teoretická východiska získávání pracovníků}

Samotnému procesu získávání pracovníků předchází personální plánování. Nezbytnou součástí práce personálního oddělení je, na základě plánovaných činností v organizaci, personální plánování. Jelikož plánování je považováno za nejdůležitější nástroj řízení organizace, představuje těžiště procesu získávání a výběru pracovníků. Koubek ${ }^{1}$ uvádí, že je nutné zjistit, jaké pracovníky bude organizace potřebovat, v jakém množství, jaké změny probíhají na trhu práce, jaké budou důsledky těchto změn pro formování pracovní síly v organizaci. Výsledkem plánování lidských zdrojů je identifikace potřeb lidských zdrojů,

\footnotetext{
${ }^{1}$ KOUBEK, J. Personální práce v malých a středních podnicích. Praha: Grada Publishing, 2003, s. 53. ISBN 80247-0602-4.
} 
které jsou nutné pro plnění potřeb a cílů organizace. Na základě identifikace potřeb lidských zdrojů jsou sestaveny popisy pracovních míst, které je potřeba obsadit.

Personálnímu plánování je věnována v literatuře zvláštní pozornost, protože představuje velmi důležitý aspekt celkové strategie podniku. Musí být s touto strategií v souladu a mělo by probíhat ve stejnou dobu jako plánování celkové strategie.

Co se týká získávání pracovníků, představuje klíčovou fázi formování pracovní síly organizace. Proces získávání pracovníků rozhoduje o tom, zda bude realizace cílů zajištěna potřebnými pracovníky, tedy rozhoduje o úspěšnosti, prosperitě a konkurenceschopnosti organizace. Je velmi podstatné získat především dostatečné množství vhodných uchazečů, zajistit maximum adekvátních informací o nich, o jejich kvalifikaci, praxi, dovednostech a schopnostech, motivaci a v neposlední řadě dodržet časový a finanční plán celého procesu.

Problematika získávání pracovníků je považována za strategický proces. Výše uvedené definice o získávání pracovníků se v literatuře ve své podstatě shodují. Dvořáková ${ }^{2}$ navíc uvádí, že je potřeba se řídit zákonem č. 262/2006 Sb., zákoníkem práce, ve znění pozdějších předpisů, a klást důraz na rovné zacházení v pracovněprávních vztazích (zamezení diskriminace) s důrazem na získávání pracovníků.

Proces získávání pracovníků zahrnuje několik navazujících kroků:

- identifikace potřeb - Koubek ${ }^{3}$ se zamýšlí i o nutnosti zvážit alternativu rozložení nově vzniklých pracovních činností, či o rozšíření stávajících pracovních činností mezi stávající zaměstnance. Z tohoto vyplývá, že zvláště v období hospodářské krize, je na podnikatele vyvíjen tlak na snižování nákladů, z toho důvodu je nutné zvážit, zda firma vůbec pracovní místo zřídí.

- popis a specifikace pracovního místa - pokud se firma rozhodne vytvořit pracovní místo, je třeba přesně definovat účel pracovního místa a požadovanou odbornost pracovníka, tedy specifikovat hlavní schopnosti pracovníka, které potřebuje při vykonávání dané pracovní pozice.

- identifikace zdrojů uchazečů - je třeba vzít v úvahu výhody a nevýhody získávání zaměstnanců $\mathrm{z}$ vnějšího trhu práce a $\mathrm{z}$ vnitřních lidských zdrojů. V první řadě musí organizace zjistit, zda je možné pokrýt tuto potřebu ze stávajících pracovníků, tedy z vnitřních zdrojů. Hlavní výhodou vnitřního trhu práce je především znalost zaměstnance. Firma investuje do tohoto zaměstnance. Pokud jej umístí na jiné pracovní místo, existuje vysoká pravděpodobnost návratnosti investice do zaměstnance zpět. Nehledě na náklady na adaptační proces. Pokud je tato možnost vyčerpaná, organizace musí zajistit pracovní síly ze zdrojů vnějších. Mezi hlavní vnější zdroje patří trh práce, respektive volné pracovní síly (např. registrovaní nezaměstnaní), absolventi škol a zaměstnanci, kteří jsou nespokojení se svým dosavadním pracovním zařazením v jiných organizacích. Co se týká vnějších zdrojů, jedná se především o pracovní síly, které jsou zaměstnané u jiného zaměstnavatele, dále absolventi škol a volné pracovní síly. Mezi další pracovní síly můžeme zařadit důchodce, studenty a ženy na mateřské dovolené. Pořadí těchto pracovních sil není náhodné. Většina podniků se snaží získat kvalifikované pracovníky. Nejlepším

\footnotetext{
${ }^{2}$ DVOŘÁKOVÁ, Z. Management lidských zdrojů. Praha: C. H. Beck, 2007, s. 133. ISBN 978-80-7179-893-4.

${ }^{3}$ KOUBEK, J. Personální práce v malých a středních podnicích. Praha: Grada Publishing, 2003, s. 56. ISBN 80247-0602-4.
} 
zdrojem jsou právě lidé zaměstnaní u jiných zaměstnavatelů. Především proto, že se neustále pohybují v daném oboru a mají přehled a potřebné znalosti. Dalším zdrojem jsou absolventi, kteří sice mají potřebnou kvalifikaci, ale nemají potřebné zkušenosti. Většinou je tedy nákladnější takového pracovníka řádně zaškolit. Zaškolení trvá delší dobu a je potřeba delší adaptační proces. Až na posledním místě se u firem umist'uje výběr z řad nezaměstnaných. Hlavním důvodem je nízká kvalifikace tohoto segmentu pracovních sil. Manažeři a majitelé firem by si ale měli uvědomit, že je možné získat touto formou i kvalifikovanou pracovní sílu. Vzhledem k přetrvávající krizi, kdy podniky byly nuceny propouštět zaměstnance díky nižší poptávce po jejich službách a produktech, je možné nalézt i kvalifikovanou, a především zkušenou pracovní sílu, i mezi registrovanými nezaměstnanými. Hlavně ve věkové skupině 50 +. Vzhledem $\mathrm{k}$ tomu, že je trend mít dynamickou a rychle se rozvíjející firmu, mají manažeři a majitelé firem vůči kvalifikovaným a zkušeným zaměstnancům v pokročilém věku výhrady, které tkví zejména ve vysoké nemocnosti a nízké efektivitě práce. Převládá názor, že lidé staršího věku nepodávají dostatečné výkony. Což je ovšem pouhý předsudek, díky němuž se firmy připravují o zkušenou pracovní sílu.

- volba vhodných metod výběru a získávání zaměstnanců - Škála metod pro výběr a získávání zaměstnanců je široká. Armstrong ${ }^{4}$ řadí mezi základní metody předvýběr na základě životopisů a dotazníků, pohovor, assessment centre a testy pracovní způsobilosti. Tyto metody se dále dělí na aktivní a pasivní (záleží do jaké míry je organizace $v$ procesu výběru a získávání pracovníků aktivní) a na vnější a vnitřní (zda hledá ve vlastních zdrojích, či z ostatních zdrojů pracovních sil). Pro organizaci je podstatné vybrat pracovníka, který je schopný dobře vykonávat požadovanou práci. Výběr metod záleží na zaměření organizace a na charakteru samotné práce.

- formulování a zveřejnění nabídky volné pracovní pozice - představuje proces, kdy se personalisté rozhodují pro nejvhodnější alternativu zveřejnění nabídky práce. Mezi nejčastěji využívané metody se stále řadí zejména inzerce na internetových portálech zaměřených na zprostředkování zaměstnání, zveřejnění nabídky na webech personálních agentur. Většina firem rovněž prezentuje nabídky volných pracovních míst v sekcích k tomu zvláště zřízených na svých vlastních webových stránkách. Pro firmy je rozhodující získat kvalitního pracovníka. Volba alternativy je také podmíněna náklady, které je potřeba vynaložit. Zejména malé firmy nevyužívají například personálních agentur, vzhledem k vysokým nákladům na získání takového specialisty.

Po realizaci výběrového řízení, a po rozhodnutí o přijetí nejlépe vyhovujícího kandidáta do pracovního procesu, následuje uzavření pracovní smlouvy a adaptační proces.

V okamžiku, kdy organizace dospěje ke konečnému rozhodnutí o vítězném kandidátovi, je výběr pracovníka úspěšně dokončen, pracovník je přijat do pracovního poměru.

Výše uvedená teoretická východiska jsou pouze všeobecným vodítkem. Každá nově vzniklá situace vyžaduje individuální řešení šité na míru dané organizaci, dle identifikace jejích potřeb. Autorka se zabývá zejména myšlenkou, jak se proces výběru zaměstnanců a jejich získávání vyvíjel v konkrétním podnikatelském prostředí.

\footnotetext{
${ }^{4}$ ARMSTRONG, M. Řízení lidských zdrojů. Praha: Grada Publishing, 2007, s. 342. ISBN 978-80-247-1407-3.
} 


\section{Analýza podnikatelského sektoru v oblasti vývoje výběru a získávání zaměstnanců}

Hlavní cíl byl směřován na zjištění změn procesu výběru zaměstnanců v období před krizí a v současnosti.

Pro analýzu byla využita technika strukturovaného rozhovoru, použity byly otázky otevřené. Otevřené otázky umožnily získat podrobnější informace a názory dotazovaných. Na předem vymezené otázky odpovědělo celkem 32 personalistů a manažerů z 24 firem působících v Ostravě. $50 \%$ z dotazovaných (16 dotazovaných) se řadí do skupiny malých fïrem (do 25 zaměstnanců), 29,2 \% (9 dotazovaných) představuje střední firmy (do 250 zaměstnanců), 20,8 \% (7 dotazovaných) velké firmy (nad 250 zaměstnanců). Autorka se zaměřila především na respondenty, kteří mají dlouhodobou praxi a jsou schopni zhodnotit vývoj ve sledované problematice.

Autorka v rámci strukturovaného rozhovoru zjištovala následující oblasti související s výběrem zaměstnanců, a to jak v době před cca 10 lety, tak v současné době (výzkum byl prováděn v druhé polovině roku 2011, v lednu roku 2012 a v únoru roku 2012), kdy působí vlivy ekonomické krize:

- Způsoby výběru zaměstnanců - Otázka: Jaké způsoby výběru zaměstnanců jste využívali pro získání pracovníků z vnějších zdrojů před cca 10 lety a nyní? Shrňte prosím nejběžnější metody a proces výběru.

- Př́stupy k personální práci v oblasti výběru zaměstnanců - Otázky: Jaký byl prŕístup k personální práci v oblasti výběru zaměstnanců v minulosti a jaký je nyní? Myslíte si, že převládal aktivní či pasivní přístup a proč? A jak vnímáte personální práci v současnosti?

- Fluktuace zaměstnanců - Otázky: Jaká je fluktuace zaměstnanců nyní a jaká byla v minulosti? Myslíte si, že ovlivní fluktuaci tzv. „přetahování“ zaměstnanců či získání kontaktů na dobré zaměstnance?

- Oblast evidence - Otázky: Jakou změnou prošla oblast evidence? Co vše evidujete nyní?

První část dotazů se zaměřovala na situaci před cca 10 lety, což odpovídalo tehdejší technické vybavenosti a dostatku pracovních sil na trhu práce.

Hlavní rysy byly zejména následující:

1. Pro získávání pracovníků z vnějších zdrojů se využívala zejména tištěná inzerce volného pracovního místa. Téměř $90 \%$ dotazovaných (28 respondentů) získávalo absolventy a méně kvalifikované pracovní síly prostřednictvím tištěné inzerce (viz obrázek $1 \mathrm{a}$ tab. 1). Méně času bylo věnováno popisu a specifikaci pracovního místa. Malé firmy využívaly také doporučení zaměstnanců (13 dotazovaných). Co se týká získávání kvalifikovaných sil, byl jich na trhu práce dostatek a personalisté neměli problém obsadit místo ve středním managementu. Velké firmy uvádějí, že na jedno pracovní místo ve středním managementu se hlásilo až 50 lidí. 
Tab. 1: Dřívější způsoby získávání zaměstnanců

\begin{tabular}{|l|r|}
\hline tištěná inzerce & $86 \%$ \\
\hline doporučení zaměstnanců & $10 \%$ \\
\hline $\begin{array}{l}\text { př́mé oslovení } \\
\text { potencionálních uchazečů }\end{array}$ & $2 \%$ \\
\hline jiný způsob & $2 \%$ \\
\hline
\end{tabular}

Zdroj: vlastní zpracování
Obrázek 1: Dřívější způsoby získávání zaměstnanců

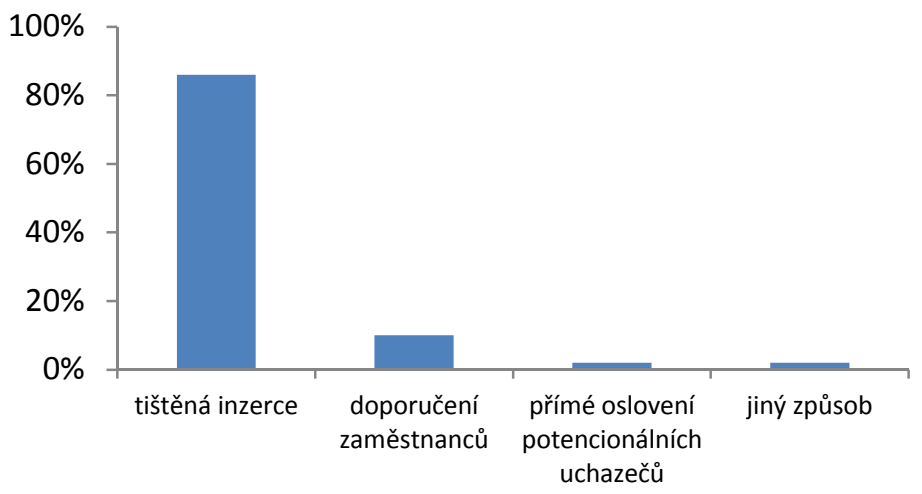

Zdroj: vlastní zpracování

2. Z rozhovorů dále vyplynula skutečnost, že převládal pasivní přístup personalistů. $\mathrm{Na}$ základě životopisů se pozvali kandidáti, kteří absolvovali jedno kolo pohovorů, a jen málo času se věnovalo struktuře pohovorů.

3. Zaměstnanci neměli obavy ze ztráty a změny zaměstnání, poptávka po práci byla dostatečná. Existovala ovšem jistá rigidita na trhu práce, kdy se zaměstnanci sice nebáli změny zaměstnání, ovšem fluktuace byla velmi nízká, málokdo měnil zaměstnání. Velké společnosti uvádějí, že pokud se zaměřovali na nábor absolventů, byl výběr velice snadný, jelikož malé firmy upřednostňovali kvalifikovanou pracovní sílu se zkušenostmi.

4. Neexistovala obava z možného headhuntingu, bylo možné najít kontakty na jakékoliv pracovníky firmy, at’ už na internetu či v tištěných dokumentech firem.

5. Personální práce $\mathrm{v}$ oblasti evidence zaměstnanců se zaměřovala na počty přijatých a počty odchozích zaměstnanců, nevedl se reporting. Existovaly pouhé karty zaměstnanců s osobními údaji a střední a velké společnosti vedly údaje o všech kandidátech, kteří prošli přijímacím řízením.

Dalši část rozhovoru se zaměrovala na zjištění změn v oblasti výběru a získávání pracovníků. $V$ současné době, a to nejen díky obtižné ekonomické situaci, firmy mění charakter personální práce s cílem získat tu nejvhodnější pracovní sílu.

1. Tabulka 2 a obrázek 2 ukazují nejběžnější způsoby výběru zaměstnanců v dnešní době. Většina dotazovaných (15 respondentů) ze středních a velkých firem uvádí, že pro získávání pracovníků z vnějšího prostředí je vytvořená speciální personální divize, která se zabývá zveřejňováním inzerátů zejména na internetu. Velký rozmach internetové inzerce souvisí s využíváním webových stránek zaměřených na získávání zaměstnanců a inzerci (například www.jobs.cz). Velká pozornost je věnována přesnému popisu a specifikaci pracovního místa. Uchazeči musí přesně vědět, na jakou pozici a pracovní místo se hlásí. Také respondenti z malých firem (13 dotazovaných) se soustředí na uveřejňování volných pracovních pozic na internetu, využívají ovšem i nabídky úřadu práce. Tištěná forma inzerátů se využívá zejména pro získání málo kvalifikované pracovní síly. Pro získání vysoce kvalifikovaných pracovníků $32 \%$ dotazovaných (10 dotazovaných) uvedlo, že využívá služeb personálních agentur, kdy ale zároveň podotýká, že se jedná o nejnákladnější způsob výběru zaměstnanců. Daleko více 
se využívá headhuntingu, neboli přímého oslovování kvalifikované pracovní síly jiných firem, s cílem získat vysoce kvalifikované pracovníky.

Tab. 2: Způsoby získávání zaměstnanců Obrázek 2: Dnešní způsoby získávaní pracovníků v současné době

\begin{tabular}{|l|r|}
\hline internet & $78 \%$ \\
\hline tištěná inzerce & $15 \%$ \\
\hline $\begin{array}{l}\text { služby personálních } \\
\text { agentur }\end{array}$ & $32 \%$ \\
\hline nabídky úřadu práce & $5 \%$ \\
\hline Headhunting & $22 \%$ \\
\hline Ostatní & $3 \%$ \\
\hline
\end{tabular}

Zdroj: vlastní zpracování

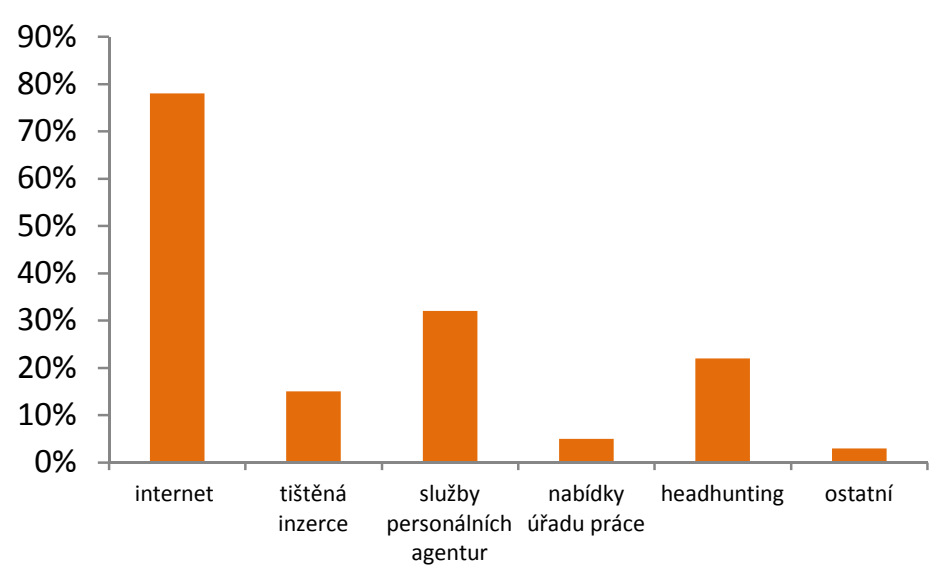

Zdroj: vlastní zpracování

2. Výběr zaměstnanců se stává jedním z klíčových aspektů personální práce. Převládá aktivní přístup personalistů, což se projevuje v požadavcích na dokumenty uchazečů (strukturovaný CV, motivační dopis, aj.), vyšším počtem kol pohovorů (které jsou systematicky propracované), psychometrickými testy s využitím kvalifikovaných psychologů (pro různé pozice speciálně sestavené testy, včetně vyhodnocení) a ověrováním referencí. V rámci aktivního př́ístupu personalistů je realizováno zacílené oslovování potencionálních uchazečů prostřednictvím tzv. spam mailů (nevyžádaný mail zaslaný vytipované skupině lidí, dle údajů, které uvedli v registraci mailu), či prostřednictvím vyhledávání na sociálních sítích, popřípadě telefonicky. Sociální sítě představují novou formu vyhledávání zaměstnancủ. Poskytují informace o konkrétních osobách a jejich zkušenostech (např. LinkedIn).

3. Získávání kvalifikovaných sil je obtížné. Střední a velké firmy uvádějí, že získat zaměstnance středního managementu přestavuje obtížný proces. Na inzerát odpoví pouze několik kandidátů a je velkým úspěchem pokud alespoň jeden kandidát vyhovuje představám firmy a přistoupí na její podmínky. V současné době si firmy uvědomují hodnotu kvalifikovaných zaměstnanců, chrání je, a proto nejsou uváděna jména ani kontakty především na internetu.

4. Převládají obavy zaměstnanců ze ztráty či změny zaměstnání. Velký vliv mají zejména závazky, které musí plnit (hypotéky, půjčky, aj.). Zaměstnanci zůstávají na nevyhovujících místech s určitou jistotou pravidelného příjmu. Fluktuace pracovníků se příliš nemění. Zejména velké firmy sledují nejen fluktuaci vně firmy, ale i uvnitř firmy (horizontálně i vertikálně).

5. Evidence personalistů $\mathrm{v}$ oblasti výběru a získávání zaměstnanců prošla také proměnou. Nyní se eviduje nejen počet přijatých a počet odchozích zaměstnanců, ale i nepřijatí uchazeči. Z analýzy vyplynulo, že evidenci provádí drtivá většina velkých a středních firem, malé firmy důkladnou evidenci nepovažují za př́iliš důležitou. 
Mezi nejdůležitější dokumenty, které si firma uchovává, patří následující:

Přijatí uchazeči:

- veškeré údaje získané ve výběrovém řízení (životopis, doklady, reference, výsledky testů)

- výsledky adaptačního procesu

- průběžná hodnocení

- výsledky pravidelných konzultací s nadřízenými za účelem dalšího vývoje kariéry ve firmě

- dochází k průběžnému hodnocení a využívá se statistických výkazů

Nepřijatí uchazeči:

- veškeré údaje získané výběrovým řízením (CV, doklady, reference, výsledky testů), a to z důvodu možného umístění uchazeče na jiné pracovní místo

- pokud uchazeč není přijat $\mathrm{z}$ důvodu vlastního odstoupení z výběrového řízení, sledují se důvody odstoupení

Odchozí zaměstnanci:

- důvody odchodu

- pokud možno i kam odchází

\section{Komentář $k$ analýze výběru zaměstnanců}

Z výše uvedeného výzkumu je patrné, jak se změnila personální práce v oblasti výběru a získávání pracovníků. V současné době získávání kvalitního pracovníka představuje opravdu strategickou záležitostí. Způsoby získávání a výběru zaměstnanců prošly značnou proměnou. Před 10ti lety byli pracovníci z vnějších zdrojů získáváni převážně prostřednictvím tištěné inzerce (téměř $90 \%$ dotazovaných). V současné době se většina firem soustředí na využívání internetu jako efektivního způsobu získávání zaměstnanců. Využívá se také headhuntingu. Výběr zaměstnanců se stává obtížným procesem. Pasivní práce personalistů se postupně mění v aktivní př́stup. Realizuje se více kol pohovorů, provádí se psychometrické testy a spolupracuje s psychology. Personalisté jsou nuceni sami vyhledávat potencionální uchazeče prostřednictvím spam mailů, sociálních sítí či telefonicky, tedy daleko ,agresivněji“ než tomu bylo v minulosti.

Co se týká uchazečů o práci a pracovníků, dochází k přeměně vnímání nutnosti pracovat. Dříve lidé nevnímali obavy ze ztráty, či změny zaměstnání tak výrazně jako dnes, kdy se ekonomika nachází v krizi. Fluktuace je nízká, ale mění se důvody, které vedou zaměstnance k setrvání v zaměstnání. Už to není jen „Zvyk“ zůstat na jednom místě, nyní se jedná o existenční obavy ze ztráty zaměstnání.

Evidence velkých a středních firem prošla také výraznou proměnou. Dnes se nejedná jen o pouhou evidenci počtu přijatých či nepřijatých uchazečů, evidují se veškeré dokumenty týkající se výběrového řízení a hodnocení uchazeče. Evidence takového charakteru má pochopitelný význam a je možné ji využít jak při snaze nalézt pracovníka na jiné pracovní místo, tak př̀ následném hodnocení pracovníka či k monitoringu fluktuačních důvodů.

\section{Závěr}

Z dlouhodobého hlediska lze očekávat především zvyšující se tlak na kvalitu zaměstnanců, a tím primárně na kvalitu obsazení personálních útvarů. Společnosti se budou jistě snažit, aby 
zvolený proces výběru a získávání zaměstnanců byl úspěšný. V současné době je nutné považovat vhodný výběr a získání pracovníka za strategický cíl.

Personální práce v oblasti výběru a získávání zaměstnanců se značně změnila. Jedná se o strategický proces, při kterém se firmy snaží nalézt ty nejvhodnější kandidáty, které podrobí důkladné analýze. Výběr pracovníků je velice náročný, kvalitní zaměstnanci jsou chráněni a fluktuace je velice nízká. I nadále lze předpokládat, že podniky budou výběru a získávání pracovníků věnovat značnou pozornost. Obecným trendem je uvědomění si významu lidských zdrojů v podniku jako hodnoty, která tvoří základ pro konkurenceschopnost a výkonnost organizace.

\section{Literatura:}

[1] ARMSTRONG, M. Řízení lidských zdrojů. Praha: Grada Publishing, 2007, 800 s. ISBN 978-80-247-1407-3.

[2] DVOŘÁKOVÁ, Z. Management lidských zdrojů. Praha: C. H. Beck, 2007, 485 s. ISBN 978-80-7179-893-4.

[3] Grafton Recruitment: www.grafton.cz

[4] GREGAR, A. Personální management. Vybrané kapitoly. Zlín: UTB, FME, 2010, 95 s. ISBN 978-80-7318-915-0.

[5] KOCIÁNOVÁ, R. Personální činnosti a metody personální práce. Praha: Grada Publishing, 2010, 224 s. ISBN 978-80-247-2497-3.

[6] KOUBEK, J. Personální práce v malých a středních podnicích. Praha: Grada Publishing, 2003, 248 s. ISBN 80-247-0602-4.

[7] VOJTOVIČ, S. Koncepce personálního řízení a řízení lidských zdrojio. Praha: Grada Publishing, 2011, 192 s. ISBN 978-80-247-3948-9.

JEL M120, M510

\section{Ing. Petra Bauerová}

studentka doktorského studia

Obchodně podnikatelská fakulta v Karviné

Slezská univerzita v Opavě

Univerzitní nám. 1934/3, 73340 Karviná

Bauerova.Petra@email.cz 